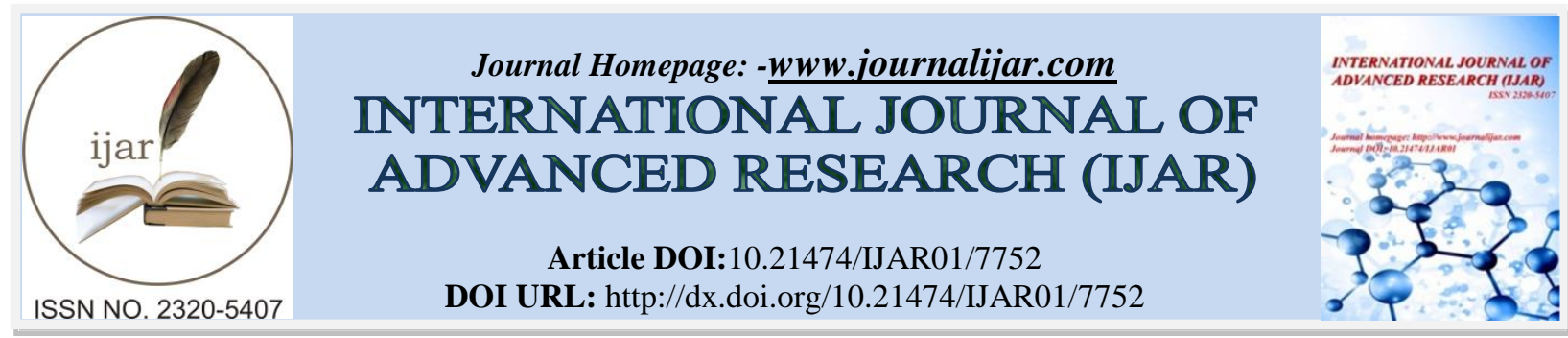

RESEARCH ARTICLE

\title{
THE FLORISTIC WEALTH AND DIVERSITY OF MYRISTICA SWAMPS, THE FRAGILE FRESH WATER ECOSYSTEM OF WESTERN GHATS.
}

Gokul C. S ${ }^{1}$, Vilas T. $\mathbf{S}^{2}$ and M. Rajendraprasad ${ }^{3 *}$.

1. Plant Systematics and Evolutionary Science Division, Jawaharlal Nehru Tropical Botanic Garden and Research Institute, Karimancode P.O., Palode, Thiruvananthapuram- 695 562, Kerala, India.

2. Plant Systematics and Evolutionary Science Division, Jawaharlal Nehru Tropical Botanic Garden and Research Institute, Karimancode P.O., Palode, Thiruvananthapuram- 695 562, Kerala, India.

3. Plant Systematics and Evolutionary Science Division, Jawaharlal Nehru Tropical Botanic Garden and Research Institute, Karimancode P.O., Palode, Thiruvananthapuram- 695 562, Kerala, India.

\section{Manuscript Info}

Manuscript History

Received: 24 July 2018

Final Accepted: 30 August 2018

Published: September 2018

Keywords:-

Fresh water swamps, Myristica, Western Ghats, Floristic Diversity.

\section{Abstract}

Kerala, the southernmost state of India, located between $8^{\circ} 17^{\prime} 30^{\prime \prime}$ and $12^{\circ} 47^{\prime} 41^{\prime \prime} \mathrm{N}$. Latitude and $74^{\circ} 52^{\prime} 47^{\prime \prime}$ and $77^{\circ} 22^{\prime} 12^{\prime \prime}$ E. Longitude. The State is boarded with sea shore of Arabian Sea and undulating hills of the Western Ghats. The Western Ghats, biodiversity hotspot of Peninsular India are well known for the existence of diverse ecosystems. The Myristica swamp is one of the rare ecosystems with a restricted distribution confined to valleys of foothills in Kerala, Uttara Karnataka, Goa and Maharashtra states. The swamps are unique for floristic wealth and ecological functioning, being the abode of amphibian richness with adaptive features, to survive in waterlogged condition. A total of 120 Myristica swamps were reported in Kerala which together contains 246 species of angiosperms belongings to 186 genera from 83 families. Among these, 77 species are endemic to India, 10 are endemic to Peninsular India, 67 are endemic to the Western Ghats, 58 are endemic to southern Western Ghats and 34 species shows cosmopolitan distribution. The majority of the endemic species belongs to the family Rubiaceae followed by Araceae, Fabaceae, Lauraceae, Dipterocarpaceae and Euphorbiaceae. The swampy members are also important in conservational status, 49 species belongs to various threat categories of IUCN, out of which, 12 species are endangered 5 species are critically endangered and 8 are vulnarable 19 are under least concern, 3 species are near threatened and 2 species are data deficient. The Floristic diversity varies from 0.710 to 0.790 and species richness and equitability varies from 1.08 to 1.32 and 0.75 to 0.83 respectively. The dominant tree species areMyristica fatua var. magnifica and Gymnacranthera canarica, being the specialist species among which M. fatua is hither to known only from Myristica Swamps, germinate, establish and survive in fresh water swampy conditions, and can be considered as the flagship species. The other Myristicaceae members viz. Myristica malabarica, Knema attenuata are commonly seen as generalist species. The riparian species like Lophopetalum wightianum, Lagerstroemia speciosa, Hydnocarpus pentandra, Holigarna 
arnottiana, Syzygium travancoricum, Vateria indica etc are the common associate species. It is observed that, all the swamps are under ecological succession due to anthropogenic or natural reasons and vegetation have been exploited which in turn is obviously in the path of extinction due to multiphase development and subsequent fragmentation. The floristic diversity indices and floristic composition and community status of Myristicaceae members also vary with vegetation succession due to changes in the selective recruitment and changes in the functional dynamism. The present investigation highlighting the floristic wealth and diversity of myristica swamps of Kerala with respects to their salient conservational features.

Copy Right, IJAR, 2018,. All rights reserved

Corresponding Author: - Rajendraprasasd. M

Address: Plant Systematics and Evolutionary Science Division, Jawaharlal Nehru Tropical Botanic Garden and Research Institute,

Karimancode P.O., Palode, Thiruvananthapuram- 695 562, Kerala, India.

\section{Introduction:-}

The Myristica swamp is physio-geographic feature of low laying areas of the Western Ghats with evergreen forest vegetation coming under the category 4C/FSI (Champion and Seth, 1968). The vegetation is characteristic with swampy adaptive nature like recalcitrant seeds, etiolate seedlings with scale leaves, knee roots or perennial rhizomes. The four storied vegetation is phanero-geophytic dominantly represented by members of Myristicaceae, Araceae, Zingiberaceae, Flacourtiaceae, Dipterocarpaceae and Arecaceae. The community status of the Myristicaceae members is structurally and functionally dominant over other members and hence the name Myristica swamps. In 1960, Krishnamoorthy first time reported this rare forest type from Kulathupuzha region of Trivandrum Forest Division. There after these swamps were identified and floristic enumeration was carried out from different States along the Western Ghats viz.Karnataka (Saldanha, 1984; Gadgil \&Chandran, 1998; Chandran \&Gadgil, 1998; Chandran\&Mest, 2001; Vasudeva et al., 2001), Goa (Santhakumaran et al., 1995, 1999) and Kerala (Pascal, 1984; A.G. Pandurangan, 2004; Vijayakumar, 2007; Rajendraprasad, 2015). In Kerala, this rare ecosystem and relic vegetation is located and identified with sacred grooves; the conserved forest patches in the middle of urbanization on religious ground or social belief (Rajendraprasad, 2015). This unique vegetation include many endemic members and red listed plants (Bourdillon, 1908; Sasidharan\& Sivarajan, 1996; Ramesh \& Pascal, 1997; Chandran\&Mest, 2001; Nayar\& Sastry, 1987). Hence the Myristica swamp, the only fresh water swamp of the Western Ghats with pristine vegetation forms the virtually live museum of ancient life forms of great biological interest. In Kerala, traditional landscapes are changing like evergreen forests changes into paddy fields or plantation of areca, coffee, rubber or drowned due to irrigation project or extermination due to forest fire. All these reasons have adverse impact on myristica swamps also (Krishnamoorthy, 1960). The existing swamps are heading towards extinction due to developmental and urbanization pressure followed by the fragmentation and isolation leads to the change in vegetational composition and ecological functioning (Rajendraprasad, 2016). Since the swamps being the edaphic formation and members are with adaptive traits, the floristic diversity is moderate with aggregate distribution and characterized with low species richness and species evenness. The present study envisaged the structural, functional and vegetational characterization of freshwater, Myristica swamp ecosystem, probably the most ancient forest type of the Western Ghats left behind with a history more than 140 million years (Chandran et al, 1999). Hence swamp forest has to be protected and conserved through careful planning and management to avoid the extinction of rare ecosystem and its adaptive floristic composition.

\section{Material and Methods:-}

Regular field explorations were carried out to selected Myristica swamps distributing in 8 districts of Kerala during 2015 -2017 covering different seasons for enumeration and analysis of floristic composition.Regional floras were used in authenticating the taxonomic identification and status of the plants were fixed using IUCN Red List. The phytosociological features and floristic diversity indices were assessed by laying quadrate of size $15 \mathrm{x} 10 \mathrm{~m}$ in randomized way and pooled to get the primary and secondary vegetation data. The data were analysed for Species richness (Mergalef, 1958), Important Value Index (Barbour et.al., 1974) Species evenness (Pielou, 1975) Floristic diversity indices (Shannon Weiner, 1963; Simpson, 1949), Species distribution (Whiteford, 1948; Curtis and McIntosh, 1958) and Biological spectrum (Raunkiaer, 1934). 


\section{Result and Discussion:-}

The fresh water swampy vegetation is unique in bio wealth and diversity, and is restricted to a very narrow ecoregion. These forest lands have been exploited and obviously are in the path of extinction due to multiphase development and urbanization.The freshwater swamp ecosystem was first reported from Travancore region of southern Western Ghats and had an extended area of 2000 ha. And now only small remnants of this ecosystem are found within an area of 150 ha. (Vijaya Kumar. et al. 2007). The existing one are also highly fragmented and isolated with nature and manmade reasons which leads to change in the structural composition and ecological functioning. All these have leads to fragmentation and isolation of these fragile and unique ecosystems. The fragmentation involves dividing up of continuous ecosystem into smaller patches and the functional dynamism is affected with changes in the floristic, ecologic and edaphic reasons.

The vegetation type of the Myristica swamps are west coast tropical evergreen type. Most of the species are evergreen type but some of the species are semi evergreen and deciduous elements are also often present. Myristica swamps all together contains 246 species of angiosperms which belongings to 186 genera coming under 83 families. The dominant species are Myristica fatua var. magnifica and Gymnacranthera canarica. of the family Myristicaceae. These two species are structurally modified so as to survive in the swampy condition, especially with knee roots and silt roots. The dominant arborascent member Myristica fatua is considered as the flagship species because of their highly restricted distribution in swampy areas only. The other Myristicaceae members like Myristica malabarica and Knema attenuata are commonly seen as dominant generalist species; hence the name Myristica Swamps .The non- Myristicaceae riparian members like Lophopetalum wightianum, Lagerstroemia speciosa, Hydnocarpus pentandra, Holigarna arnottiana, Syzygium travancoricum, Vateria indica etc. are also well distributed in this forest type and sometime fall in the dominant category with the advancement of ecological succession. The dense vegetation of myristica swamps are four storied with continues canopy. Top canopy constitutes above $20 \mathrm{~m}$ height trees. This layer is composed of specie like Gymnacranthera canarica, Lophopetalumwightianum, Lagerstroemia speciosa, Hopea parviflora and Neolamarckia cadamba. The climbers also reach up this layer and formed a closed canopy, competing for light and space. The climbers such as Chilocarpus denudatus, Kunstleria keralensis, Gnetum ula and Entada rheedii, are the major components of the upper canopy. The sub canopy is within the height ranges of 15-20 meter and consists of medium sized trees like Myristica fatua, Myristica malabarica, Knema attenuata, Hydnocarpus pentandra and Xanthophyllum arnottianum. Different growth stages of top canopy trees are also common in this stratum. The shrubby layer of the vegetation is mostly composed of seedlings and saplings of both top canopy trees as well as that of sub canopy, apart from typical shrub species likePandanus kaida, Schumannianthus virgatus and different species of Calamus and Ochlandra. The floor is inundating in major part of the year, hence the ground vegetation is very thin, composed of different species of Lagenandra.

The species richness of Myristica swamp is very low when compared to other forest types. The low value for species richness is account by the prevailing edaphic conditions and ecological requirement of swampy species. The floristic diversity, irrespective of the size of myristica swamp, shows low value when compared to other ecosystems of Western Ghats. The average Simpsons index value is 0.74 , Shannon Weiner index is 2.71 . The variety ratio of the myristica swamp is 0.137 , and the value for equitability is 0.79 and that of Species richness is 1.29 .

The Community Status of Important Tree species of Myristica swamps (table .1)

\begin{tabular}{|l|l|l|}
\hline Sl. no. & Name & IVI \\
\hline 1 & Myristica fatua var. magnifica & 84.12 \\
\hline 2 & Gymnacranthera canarica & 78.29 \\
\hline 3 & Hydnocarpus pentandra & 34.15 \\
\hline 4 & Myristica malabarica & 29.50 \\
\hline 5 & Holigarna arnottiana & 29.46 \\
\hline 6 & Vateria indica & 26.17 \\
\hline 7 & Lophopetalum wightianum & 23.49 \\
\hline 8 & Lagerstroemia speciosa & 20.17 \\
\hline 9 & Xanthophyllum arnottianum & 19.18 \\
\hline 10 & Syzygium travancoricum & 17.20 \\
\hline 11 & Hopea parviflora & 14.23 \\
\hline 12 & Aporusa lindleyana & 13.35 \\
\hline 13 & Knema attenuata & 13.20 \\
\hline 14 & Neolamarckia cadamba & 11.34 \\
\hline
\end{tabular}


The relative occurrence and community status of Myristica fatua and Gymnacranthera canarica in terms of IVI are very high and above the normal hence considered as specialist species compared to other swampy species, generalist species. The community status of non-swampy species is very low, being considered as associate species (table 1).

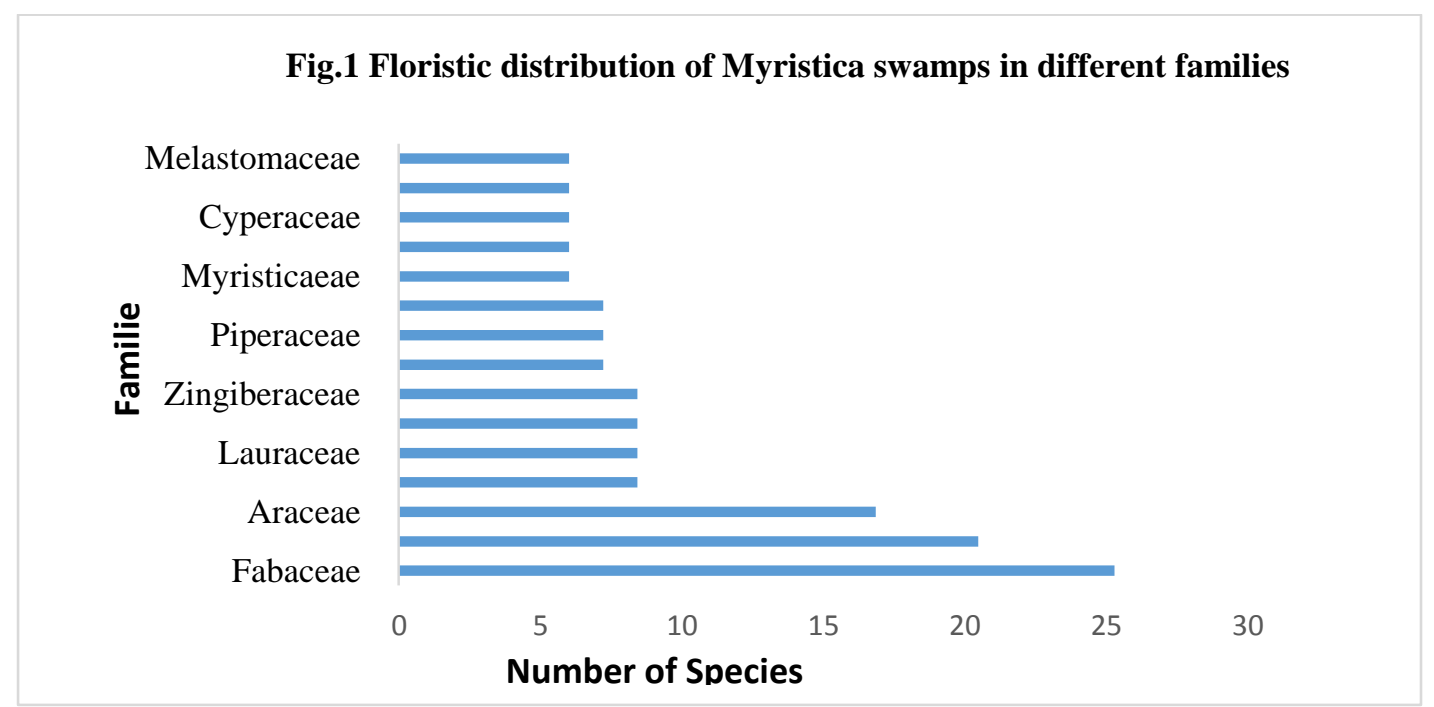

The dominant family is Fabaceae with highest number of species. Nearly $25.3 \%$ of species belonged to this family followed by Rubiaceae (20.48\%), third dominant family is Araceae consisting of (16.86\%) other dominant families as follow: Euphorbiaceae (8.43), Lauraceae (8.43), Oleaceae (8.43), Zingiberaceae (8.43) (fig 1). Plant diversity in different stages of succession is in increasing trend, observed towards the advancement of successions. The initial establishment is due to edge effect, change in the environmental parameters, causing the decline in population of Myristica fatua and Gymnacranthera canarica and increase in number and IVI value of non-swampy species, generalist and associate species.

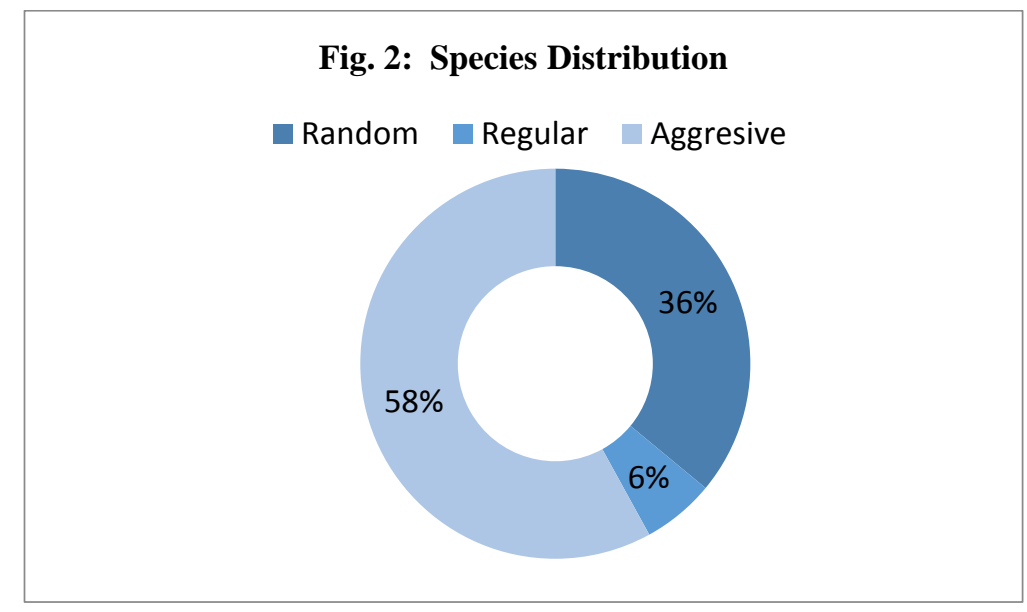

With regard to representation of various distributions level in the flora of Myristica swamps 36\% of taxa shows random distribution, $6 \%$ are regular and $58 \%$ species shows aggressive distribution pattern (Fig. 2). 


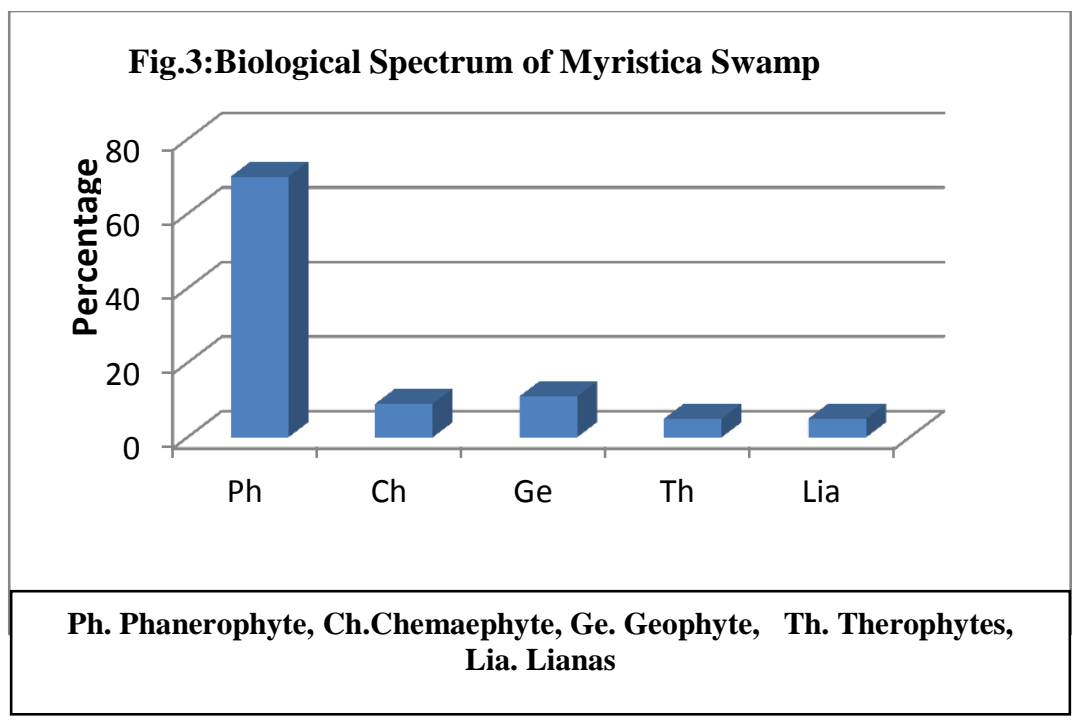

Structurally the swamp is dominated with tree forms (70\%) followed by geophytes (11\%) and chamaephytes (9\%). The Lianas (5\%) and therophytes (5\%) are remaining members which considerably control the physiognomy of the swamps.The different structural forms occupy different space with different association having different boundaries, each with a varying degree of uniformity in structure and composition. The distribution of first storied trees and entangled lianas are responsible agents of controlling micro climate and micro niche of the ecosystem (fig 3 ).

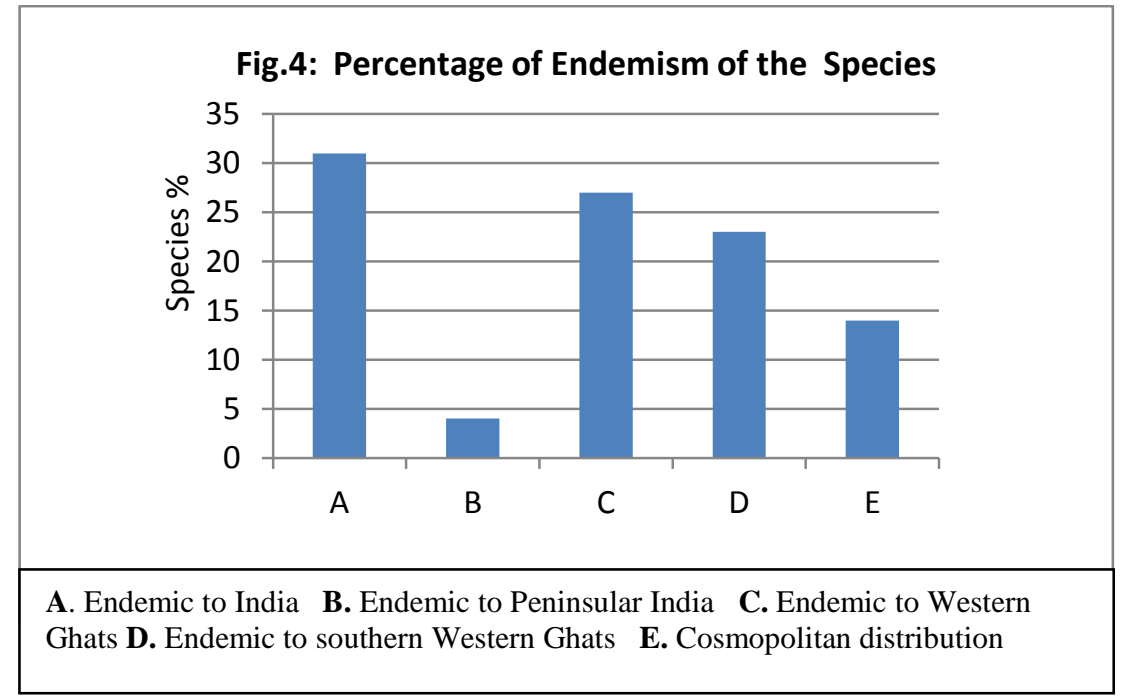

Among 246 species of flowering plants recorded from the swamps, 77 are endemic to India, 10 are endemic to peninsular India, 67 are endemic to Western Ghats, 58 are endemic to southern Western Ghats and 34 species show cosmopolitan distribution (fig .4). In family, high representation of endemism is noted in Rubiaceae followed by Araceae, Fabaceae, Lauraceae, Dipterocarpaceae and Euphorbiaceae. About 49 species of flowering plants belonging to various threat categories of IUCN, among which 12 species are endangered, 5 are critically endangered and 8 are vulnerable 19 are under least concern, 3 species are near threatened and 2 species are data deficient.

\section{Conclusion:-}

The Western Ghats in Peninsular India is one among the biodiversity hot spots in the world and one of the three endemic hot spotsof India. It stands foremost in the representation of endemic elements in the Indian flora. The flora of Myristica Swamps shows high degree of endemism. In 1992, Panwar et al. highlighted the vegetation and most critically needing conservation. The Swamp vegetation is edaphic formations with physio-geographic features of 
low laying area of Western Ghats resulting from the hydro and geomorphic peculiarities. The swamp supports characteristic amphibian evergreen vegetation with the specialist and generalist species; dominated with Myristicaceae family. The specialist members are structurally modified to overcome the seasonal flooding. The floristic diversity and species richness is always lower than other forest types of Western Ghats, indicating the specific edaphic and ecological requirements of these species, habitat specialization which permits only adaptive species to survive in swampy area. Again the vegetation is with high percentage of endemism. The swamp inhabiting threatened specialist species like Myristica fatua var. magnifica and Gymnacranthera canarica population are declining during the advancement of ecological succession. The fragility of ecosystem and unique biota invite the immediate alternative of the conservation strategies required to protect the existing swamps.

\section{Reference:-}

1. A.G. Pandurangan and M.Rajendraprasad., 2004. Floristic and Structural Analysis of Myristica Swamp in Kulathupuzha. Project report. Kerala State Forest Department

2. Bourdillion, T.F., 1908. The forest trees of Travancore Govt. Press, Trivandrum xxxii+456pp

3. Champion, H.G., Seth, S.K., 1968. A revised survey of the forest type of India. Government of india.Xxiii+404pp.

4. Chandran, M.D.S., Mesta, D.K., 2001. On the conservation of the Myristica swamps of the Western Ghats. In: Forest Genetic Resources: Status, Threats, and Conservation Strategies. Eds. Uma Shanker, R., Ganeshaih, K.N., and Bawa, K.S. Oxford and IBH, New Delhi: 1-19

5. Chandran, M.D.S., Gadgil, M., 1998. Sacred groves and sacred trees of Uttara Kannada. In: B. Saraswati (ed) Lifestyle and Ecology, Indira Gandhi National Centre for Arts, New Delhi.

6. Chandran, M.D.S., Mesta, D.K. and Naik, M.B., 1999. Myristica swamp of Uttara Karnataka district. My forest 35(3): 207-222

7. Curtis, J.T., and M.P. McIntosh., 1950. The interrelations of certain analytic and synthetic phytosociological characters. Ecol. 31:434-55

8. Gadgil, M., Chandran. M.D.S., 1989. Environmental impact of forest based industries on the evergreen forests of Uttara Kannada district, a case study (Final Report). Department of Ecology and Environment, Government of Karnataka, Bangalore

9. Krishna Moorthy, K., 1960. Myristica swamps in the evergreen forests of Travancore. Indian Forester 86(5): 314-315

10. Margalef, R., 1958. Information theory in Ecology. General systematics. 3: 36-71

11. Nayar, M.P., Sastry, A., 1987. Red Data Books of Indian Plants. Vol I, Botanical Survey of India, Calcutta. p. 147-159.

12. Pascal, J. P., 1984. Les forêtsdenseshumidessempervirentes des Ghâtsoccidentaux. Ecologie, structure, floristique ET succession. Inst. fr.Pondichéry, trav. sec. sci. tech. 20. (English version: 1988. Wet evergreen forests of the Western Ghats of India.)

13. Pielou, E.C., 1975. Ecological diversity. John Willey and sons. New York.

14. Raunkiaer., 1934. Plant life forms. Clarendon, Oxford.

15. Ramesh, B.R. \& J.P. Pascal., 1997. Atlas of Endemics of the Western Ghats (India). Distribution of Tree Species in the Evergreen and Semi-evergreen forests. InstitutFrançais de Pondichery

16. Rajendraprasad,M., 2016. Ecology and Conservation of Freshwater Ecosystem Western Ghats- Kerala. Project report Department of Biotechnology, Government of India.

17. Santhakumaran, L.N., Singh, A., Thomas, V.T., 1995. Description of a sacred grove in Goa (India), with notes on the unusual aerial roots produced by its vegetation. Wood. Oct Dec: 24-28

18. Saldanha, C.J., 1984. Flora of Karnataka. Oxford and IBH publishing co, New Delhi. Vol. I.

19. Sasidharan, N., Sivarajan, V.V., 1996. Flowering Plants of Thrissur Forests. Scientific Publishers, Jodhpur.

20. Shannon, C.E., Weiner. W., 1963. The Mathematical Theory of Communication. University of IllinoisPress, Urbana, U.S.A.

21. Simposon, E.H., 1949. Measurement of diversity. Nature 163: 688

22. Vasudeva, R., Raghu, R., Dasappa, H.B., Umasankar, R., and Ganesh, N., 2001. Population structure, reproductive biology and conservation of Semicarpus kathalekunensis: a critically endangered freshwater swamp tree species of the Western Ghats In: Umasankar, R., Ganeshaih, K.N., and Bawa, K.S., (cds), Forest Genetic resources: Status, Threat and Conservation strategies, Oxford and IBH publications, New Delhi. 211233 pp.

23. P. Vijayakumar., K. K. Ramachandran., K. Swarupanandan., Thomas P. Thomas., 2007. Mapping Biodiversity of the Myristica Swamps in Southern Kerala. Final Report Project KFRI 452/04. 
24. Whiteford, P.B., 1948. Distribution of wood land plants in relation to succession and clonal growth. Ecology 30:199-208. 